\title{
Aortic Butyrylcholinesterase is Reduced in Spontaneously Hypertensive Rats
}

\section{Kristína SZMICSEKOVÁ ${ }^{1,2,3}$, Lenka BIES PIVÁČKOVÁ ${ }^{1,4}$, Zuzana KILIÁNOVÁ ${ }^{1,4}$, Lubica SLOBODOVÁ ${ }^{1,4}$, Peter KŘENEK ${ }^{1}$, Anna HRABOVSKÁ ${ }^{1,4,5}$}

${ }^{1}$ Department of Pharmacology and Toxicology, Faculty of Pharmacy, Comenius University in Bratislava, Slovak Republic, ${ }^{2}$ Hospital Pharmacy, National Institute of Cardiovascular Diseases, Bratislava, Slovakia, ${ }^{3}$ Centre Borelli, Cognac G, Université de Paris, France, ${ }^{4}$ Institute of Pharmacology, Faculty of Medicine, Slovak Medical University in Bratislava, Slovak Republic, ${ }^{5}$ Biomedical Research Center, University Hospital, Hradec Kralove, Czech Republic

Received February 26, 2021

Accepted May 18, 2021

Epub Ahead of Print September 10, 2021

\section{Summary}

Despite the fact that vessels have sparse cholinergic innervation, acetylcholine (ACh), the primary neurotransmitter of parasympathetic nervous system, has been commonly used in physiological experiments to assess vascular function. ACh is hydrolyzed by two cholinesterases (ChE), namely acetylcholinesterase and butyrylcholinesterase (BChE). However, little is known about these enzymes in blood vessels. The aim of the project was to characterize the expression and activity of ChE in rat aorta. As the effect of ACh on vascular tone depends on the presence of endothelium, Wistar rats were used as a model with intact endothelium and spontaneously hypertensive rats as a model of impaired endothelial function. Relative expressions of both ChE in different parts of the aorta were determined using RT-qPCR. Enzyme activities were assessed in tissue homogenates by Ellman's assay. Here we showed that both ChE are present in each part of rat aorta, while mRNA is more abundant for BChE than for $\mathrm{AChE}$, irrespective of aortic compartment or genotype. Normotensive Wistar rats possess higher aortic mRNA expression and activity of BChE compared to SHR. We concluded that BChE is the dominant type of $\mathrm{ChE}$ in rat aorta and it might play an important role in the regulation of vascular tone.

\section{Key words}

Rat aorta - Acetylcholinesterase - Butyrylcholinesterase • Spontaneously hypertensive rats

\section{Corresponding author}

A. Hrabovska, Department of Pharmacology and Toxicology, Faculty of Pharmacy, Comenius University, Odbojárov 10, 83104 Bratislava, Slovak Republic. E-mail: hrabovska@fpharm.uniba.sk

Acetylcholine (ACh) is frequently used to assess endothelial function of isolated vessels. ACh increases arterial pressure during normal vascular tone, whereas the opposite is observed during increased vascular tone (Furchgott 1991, Norel et al. 1996). Notably, ACh has the ability to relax a precontracted aorta, provided an intact endothelium (Furchgott 1991, Norel et al. 1996, Félétou and Vanhoutte 2006). Despite routine use of ACh in vascular physiological experiments, little is known about its degradation enzymes in blood vessels, acetylcholinesterase (AChE) and butyrylcholinesterase (BChE).

Here, we address this knowledge gap by examining the mRNA expression and activity of both enzymes, $\mathrm{AChE}$ and $\mathrm{BChE}$, in three aortic segments: arcus aortae, aorta thoracalis and aorta abdominalis. Additionally, we compared healthy vessels from Wistar rats to the corresponding regions of the vessels from spontaneously hypertensive rats (SHR), which we and others (Félétou and Vanhoutte 2006) have observed to display differential responses to ACh.

Male Wistar rats, a model of the intact

PHYSIOLOGICAL RESEARCH • ISSN 1802-9973 (online) - an open access article under the CC BY-NC-ND 4.0 license (c) 2021 Institute of Physiology of the Czech Academy of Sciences, Prague, Czech Republic Fax +420 241062 164, e-mail: physres@fgu.cas.cz,www.biomed.cas.cz/physiolres 
endothelium ( $\mathrm{n}=6)$ and SHR, a model with impaired endothelium ( $\mathrm{n}=6), 12$ weeks of age were euthanized by $\mathrm{CO}_{2}$ and the aorta was dissected into three parts (arcus aortae, aorta thoracalis and aorta abdominalis), frozen immediately in liquid nitrogen and stored at $-80{ }^{\circ} \mathrm{C}$. All experiments were approved by the State Veterinary and Food Administration of the Slovak Republic. The study was conducted in accordance with the Basic \& Clinical Pharmacology \& Toxicology policy for experimental and clinical studies (Tveden-Nyborg et al. 2018).

Tissue extractions and activity Ellman's activity were performed as described before (Dingova et al. 2014), using an equal amount of protein from each part of the aorta quantified by Pierce ${ }^{\mathrm{TM}}$ BCA Protein Assay. As substrates, $1 \mathrm{mM}$ acetylthiocholine (for both $\mathrm{ChE}$ ) or $1 \mathrm{mM}$ butyrylthiocholine (selective for BChE) were used. For AChE activity, the samples were preincubated with the BChE inhibitor, tetraisopropyl-pyrophosphoramide $(1 \mathrm{mM})$, for $30 \mathrm{~min}$ prior to substrate. BChE activity was determined in the presence of butyrylthiocholine. Enzyme activity was detected at $30 \mathrm{~s}$ intervals for $30 \mathrm{~min}$ and expressed as $\Delta$ O.D./min (Dingova et al. 2014).

Total RNA was isolated from intact aorta samples with TRI Reagent (Sigma Aldrich) and $335 \mathrm{ng}$ was used for RT-qPCR employing primers and reaction conditions as described before (Kilianova et al. 2020, Targosova et al. 2021). Gene expression was normalized to Actb and Hprt1 and relative expression values were normalized to rat brain due to high expression of AChE and BChE. Amplification efficiencies were determined for each primer pair using the software LinRegPCR according to the methods of Ruijter et al. (2009). The amplification efficiency values for $\mathrm{AChE}$ and $\mathrm{BChE}$ were 1.864 and 1.809 , respectively.

Two-factor ANOVAs (rat model $\times$ aorta segment) with Tukey's post hoc test was used. We computed effect sizes (Cohen's f) for each ANOVA to ensure that significant main effects and interaction effects exceeded the minimum effect size determined by a sensitivity power analysis.

The mRNA expression of both ChEs was detected in each segment of the aorta of both animal models (Fig. 1). Surprisingly, BChE is more abundant than $\mathrm{AChE}$ in all aortic segments, ranging from a 240- to 425 -fold increase in Wistar rats and a 140 - to 220 -fold increase in SHR. AChE relative expression revealed differences between aorta segments $\left(F_{2,22}=14.21\right.$, $p=0.0001)$. The main effect of rat model $\left(F_{1,22}=2.777\right.$, $p=0.109)$ and the interaction $\left(F_{2,22}=0.837, p=0.446\right)$ were not significant. Relative expression of AChE in arcus aortae was higher in comparison to the other segments in Wistar rats (Fig. 1a). For BChE, we observed main effects for both aorta segments $\left(F_{2,22}=21.1, p<0.0001\right)$ and rat model $\left(F_{1,22}=12.93, p<0.01\right)$, although the interaction was not significant $\left(F_{2,22}=1.229, p=0.312\right)$. The relative expression of BChE was lower in aorta thoracalis than arcus aortae and aorta abdominalis in both animal models (arcus aortae vs. aorta thoracalis in SHR showing trend) (Fig. 1b). Overall, the expression of $\mathrm{BChE}$ is lower in the aorta of SHR regardless of the anatomical division.

\section{a}
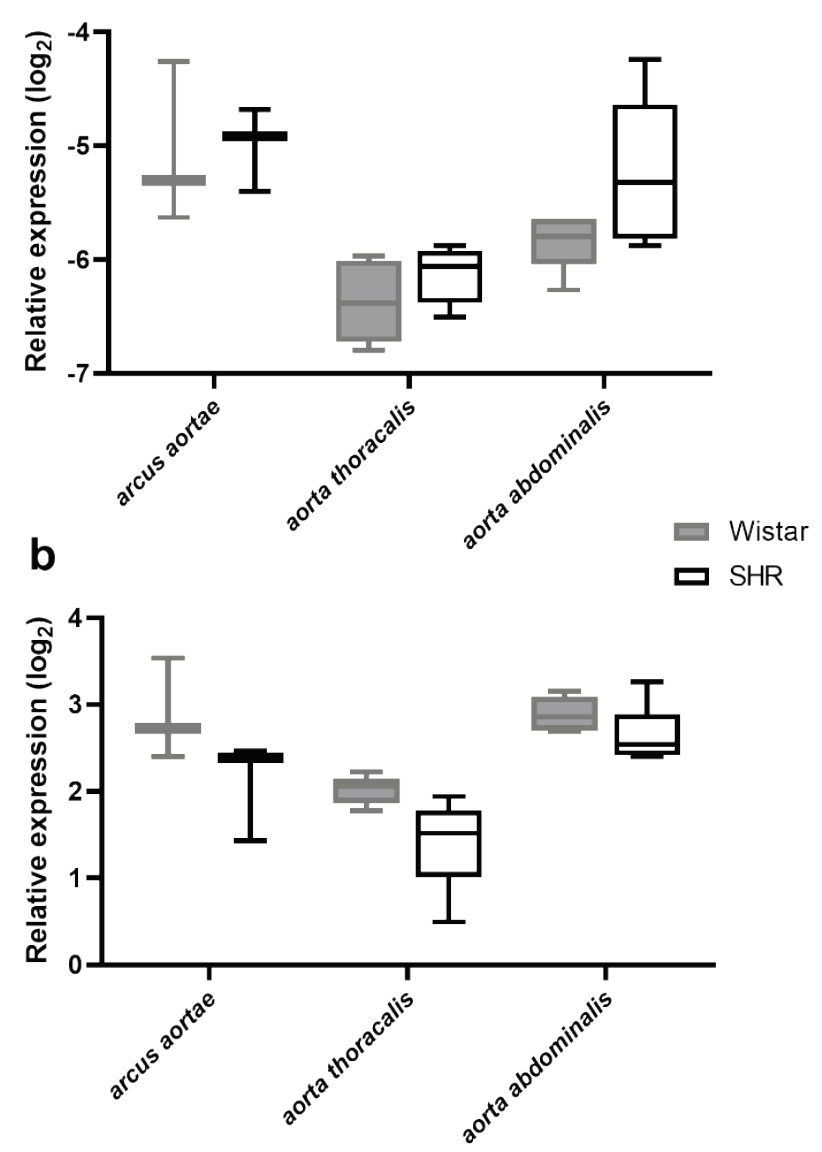

Fig. 1. Relative expression of $A C h E$ in different segments of rat aorta assessed by RT-qPCR: Box plots show the relative expression of $\mathrm{AChE}(\mathbf{a})$ and $\mathrm{BChE}(\mathbf{b})$ in different segments of rat aorta. Boxes extend from the $25^{\text {th }}$ to $75^{\text {th }}$ percentiles with the line representing the median and the whiskers displaying the minimum and maximum values. Individual values are normalized to brain expression levels (values set to 0 on $\log _{2}$ scale). The number of animals used for mRNA extraction and RT-qPCR in each group is: arcus aortae $(n=3)$, aorta thoracalis $(n=5)$, aorta abdominalis $(\mathrm{n}=6)$. 
Both ChE activities were detected in all segments of aorta in both studied models, with BChE activity markedly exceeding AChE activity (Fig. 2). Both $\mathrm{ChE}$ activities revealed significant main effects for aorta segment (AChE: $F_{2,28}=80.50, \quad p<0.0001$; BChE: $F_{2,29}=174.0, p<0.0001$ ), rat model (AChE: $F_{1,28}=23.14$, $p<0.0001$; BChE: $\left.F_{1,29}=132.8, \quad p<0.0001\right)$ and the interaction (AChE: $F_{2,28}=10.04, \quad p=0.0005$; BChE: $\left.F_{2,29}=46.24, p<0.0001\right)$. Activity of AChE in Wistar rats decreased in the following order: arcus aortae $>$ aorta abdominalis $>$ aorta thoracalis (Fig. 2a). AChE in SHR aorta segments were comparable to Wistar, with the exception of aorta abdominalis, where AChE activity was increased in SHR. BChE activity in arcus aortae was roughly twice the activity observed in aorta thoracalis and aorta abdominalis in Wistar rats (Fig. 2b). Similar to mRNA, BChE activity was decreased in arcus aortae and aorta thoracalis of the SHR in comparison to Wistar.

$\mathrm{BChE}$ activity exceeds that of $\mathrm{AChE}$ in numerous tissues (Li et al. 2002), supporting our finding that $\mathrm{BChE}$ is the dominant $\mathrm{ChE}$ in the rat aorta. The physiological importance of high $\mathrm{BChE}$ activity, however, remains uncertain. Vascular $\mathrm{BChE}$ may compensate for low $\mathrm{BChE}$ activity in rat plasma, compared to other species ( $\mathrm{Li}$ et al. 2002). Indeed, in contrast to rats, where we detected low AChE and substantial BChE activities, the aorta thoracalis of mice showed very low levels of both AChE and BChE activities (data not shown).

The presence of muscarinic receptors in the aorta suggests that the primary function of vascular ChE is to regulate local $\mathrm{ACh}$ to prevent over-excitation of muscarinic receptors. The origin of ACh that would affect vascular $\mathrm{ACh}$ receptors is ambiguous. Aortic $\mathrm{BChE}$ may buffer the vessel from ACh arising from the blood, produced for example by T-cells (Kawashima et al. 2015). The more distant neuronal or non-neuronal sources are, despite a low rat plasma BChE activity, unlikely due to a rather high plasma AChE activity (Li et al. 2002). Aortic BChE may also degrade spilledover ACh (Nervo et al. 2019) from the heart, which would explain our observation that the highest ChE activities reside in the arcus aortae, the aortic region proximal to the heart. Nevertheless, "cholinergic contamination" arising from parasympathetic innervation at the base of the heart is plausible.

Another source of $\mathrm{ACh}$ that could serve as a substrate for vascular BChE could be the vessel itself. Recently, the existence of many non-neuronal cholinergic tissues were described, playing important roles in physiological and pathological processes (Beckmann and Lips 2013). The action of non-neuronal ACh is usually autocrine/paracrine (Wessler and Kirkpatrick 2008). We speculate that the aorta may represent another nonneuronal cholinergic tissue, although additional experiments examining the presence of enzymes and transporters necessary for local ACh synthesis, release, and degradation in the aorta are required.

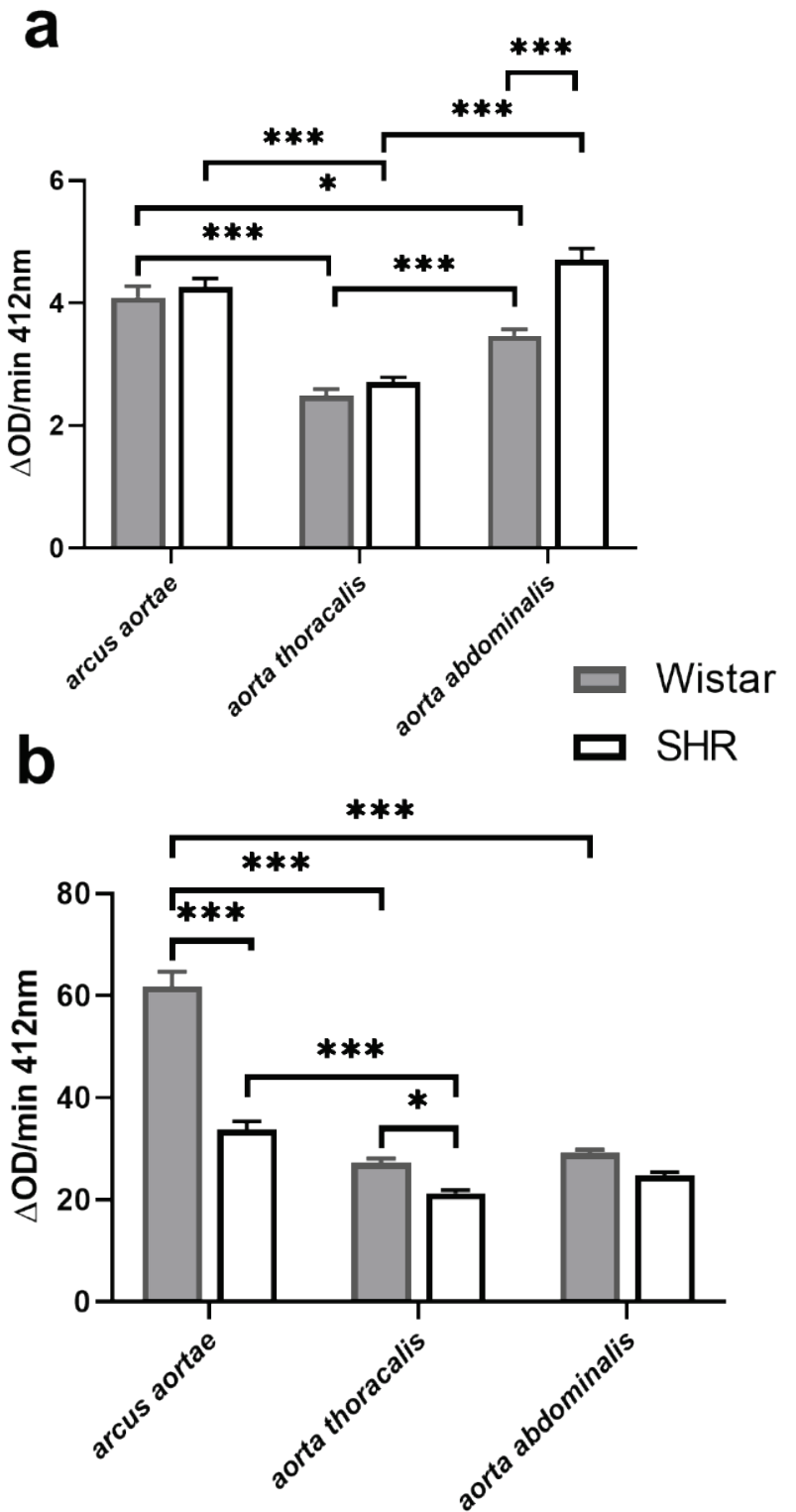

Fig. 2. $A C h E$ and $B C h E$ activity in different segments of rat aorta assessed by Ellman's assay: Bar graphs depict enzyme activity of AChE (a) and BChE (b) in different segments of rat aorta. Data are expressed as mean + SEM. The number of animals used for Ellman's assay in each group is: arcus aortae $(n=6)$, aorta thoracalis $(n=6)$, aorta abdominalis $(n=6) . p \leq 0.05 \quad(*)$, $p \leq 0.01(* *), p \leq 0.001(* * *)$. 
Hydrolysis of ACh may not be the sole role of aortic BChE, considering its broad substrate specificity, ability to cleave bulkier substrates, and relationship to lipid metabolism (Lockridge 2015, Chen et al. 2016, Santarpia et al. 2013, Hrabovska et al. 2006, Dingova et al. 2016). Moreover, there is clinical evidence of a strong correlation between plasma BChE activity and triacylglycerol and LDL cholesterol levels (Iwasaki et al. 2007), markers associated with risk of endothelial dysfunction and subsequent atherosclerosis. Thus, the presence of $\mathrm{BChE}$ in blood vessels could function as a detoxification-defense mechanism to prevent deposition of harmful substances as well as lipid components in the blood vessels and consequently the development of atherosclerosis.

SHR are characterized by progressive deterioration of the anatomical, morphological, and physiological characteristics of vessels. Moreover, SHR develop endothelial dysfunction and subsequently the vasodilatory response to $\mathrm{ACh}$ is modified (Félétou and Vanhoutte 2006). Our results confirmed an impaired cholinergic system in SHR aorta. While SHR had normal aortic AChE mRNA levels and activity, BChE mRNA levels and activity were reduced, suggesting involvement of $\mathrm{BChE}$ in the regulation of $\mathrm{ACh}$ signaling. Additionally, participation of $\mathrm{BChE}$ in vascular pathogenesis is supported by the aforementioned noncholinergic catalytic properties and clinical evidence. Endothelial dysfunction is associated with essential hypertension and cardiovascular risk factors such as aging, hypercholesterolemia and diabetes mellitus (Hadi et al. 2005). These conditions are linked to $\mathrm{ChE}$, primarily BChE levels in related tissues (Iwasaki et al. 2007). Endothelial dysfunction, also characterized by reduced bioavailability of NO (Bonetti et al. 2003), increases oxidants and the expression of adhesion molecules involved in the initiation and progression of atherosclerotic plaque formation and the incidence of cardiovascular events (Félétou and Vanhoutte 2006). We hypothesize that vascular BChE acts as a detoxifying enzyme for these molecules and is involved in the prevention of atherosclerosis. This is consistent with the fact that plasma $\mathrm{BChE}$ activities correlate with higher LDL and triacylglycerol levels, known risk factors for atherosclerosis.

Our results reveal that $\mathrm{BChE}$ is the dominant $\mathrm{ChE}$ in the rat aorta, with the highest activity in the arcus aortae. BChE levels are lower in the aorta of SHR. We assume that aortic $\mathrm{BChE}$ is responsible for the regulation of ACh signaling and participates in angioprotection. Future studies should use selective AChE/BChE inhibitors to delineate the roles of each $\mathrm{ChE}$ in vasodilatory responses to $\mathrm{ACh}$ in compartments of the aorta.

\section{Conflict of Interest}

There is no conflict of interest.

\section{Acknowledgements}

This study was supported by the Ministry of Education, Science, Research, and Sport of the Slovak republic (VEGA 1/0815/21, APVV-19-0458 and SK-FR-19-0005) and by the Comenius University in Bratislava (UK-3432020).

\section{References}

BECKMANN J, LIPS KS: The non-neuronal cholinergic system in health and disease. Pharmacology 92: 286-302, 2013. https://doi.org/10.1159/000355835

BONETTI PO, LERMAN LO, LERMAN A: Endothelial dysfunction. Arterioscler Thromb Vasc Biol 23: 168-175, 2003. https://doi.org/10.1161/01.ATV.0000051384.43104.FC

CHEN VP, GAO Y, GENG L, STOUT MB, JENSEN MD, BRIMIJOIN S: Butyrylcholinesterase deficiency promotes adipose tissue growth and hepatic lipid accumulation in male mice on high-fat diet. Endocrinology 157: 3086-3095, 2016. https://doi.org/10.1210/en.2016-1166

DINGOVA D, LEROY J, CHECK A, GARAJ V, KREJCI E, HRABOVSKA A: Optimal detection of cholinesterase activity in biological samples: modifications to the standard Ellman's assay. Anal Biochem 462: 67-75, 2014. https://doi.org/10.1016/j.ab.2014.05.031

DINGOVA D, FAZEKAS T, OKULIAROVA P, STRBOVA J, KUCERA M, HRABOVSKA A: Low plasma cholinesterase activities are associated with deficits in spatial orientation, reduced ability to perform basic activities of daily living, and low body mass index in patients with progressed Alzheimer's Disease. J Alzheimers Dis 51: 801-813, 2016. https://doi.org/10.3233/JAD-151060 
FÉLÉTOU M, VANHOUTTE PM: Endothelial dysfunction: a multifaceted disorder (The Wiggers Award Lecture). Am J Physiol Heart Circ 291: H985-H1002, 2006. https://doi.org/10.1152/ajpheart.00292.2006

FURCHGOTT RF: Endothelium-dependent relaxation, endothelium-derived relaxing factor and photorelaxation of blood vessels. Semin Perinatol 15: 11-15, 1991.

HADI HAR, CARR CS, AL SUWAIDI J: Endothelial dysfunction: cardiovascular risk factors, therapy, and outcome. Vasc Health Risk Manag 1: 183-198, 2005.

HRABOVSKA A, DEBOUZY JC, FROMENT MT, DEVINSKY F, PAULIKOVA I, MASSON P: Rat butyrylcholinesterase-catalysed hydrolysis of N-alkyl homologues of benzoylcholine. FEBS J 273: 1185-1197, 2006. https://doi.org/10.1111/j.1742-4658.2006.05144.x

IWASAKI T, YONEDA M, NAKAJIMA A, TERAUCHI Y: Serum butyrylcholinesterase is strongly associated with adiposity, the serum lipid profile and insulin resistance. Intern Med 46: 1633-1639, 2007. https://doi.org/10.2169/internalmedicine.46.0049

KAWASHIMA K, FUJII T, MORIWAKI Y, MISAWA H, HORIGUCHI K: Non-neuronal cholinergic system in regulation of immune function with a focus on $\alpha 7$ nAChRs. Int Immunopharmacol 29: 127-134, 2015. https://doi.org/10.1016/j.intimp.2015.04.015

KILIANOVA Z, CIZNAROVA N, SZMICSEKOVA K, SLOBODOVA L, HRABOVSKA A: Expression of cholinesterases and their anchoring proteins in rat heart. Can J Physiol Pharmacol 98: 473-476, 2020. https://doi.org/10.1139/cjpp$\underline{2019-0565}$

LI B, STRIBLEY JA, TICU A: Abundant tissue butyrylcholinesterase and its possible function in the acetylcholinesterase knockout mouse. J Neurochem 75: 1320-1331, 2002. https://doi.org/10.1046/j.1471-4159.2000.751320.x

LOCKRIDGE O: Review of human butyrylcholinesterase structure, function, genetic variants, history of use in the clinic, and potential therapeutic uses. Pharmacol Ther 148: 34-46, 2015. https://doi.org/10.1016/j.pharmthera.2014.11.011

NERVO A, CALAS A-G, NACHON F, KREJCI E: Respiratory failure triggered by cholinesterase inhibitors may involve activation of a reflex sensory pathway by acetylcholine spillover. Toxicology 424: 152232, 2019. https://doi.org/10.1016/j.tox.2019.06.003

NOREL X, WALCH L, CONSTANTINO M: M1 and M3 muscarinic receptors in human pulmonary arteries. Br J Pharmacol 119: 149-157, 1996. https://doi.org/10.1111/j.1476-5381.1996.tb15688.x

RUIJTER JM, RAMAKERS C, HOOGAARS WMH, KARLEN Y, BAKKER O, VAN DEN HOFF MJB, MOORMAN AFM: Amplification efficiency: linking baseline and bias in the analysis of quantitative PCR data. Nucleic Acids Res 37: E45, 2009. https://doi.org/10.1093/nar/gkp045

SANTARPIA L, GRANDONE I, CONTALDO F, PASANISI F: Butyrylcholinesterase as a prognostic marker: a review of the literature. J Cachexia Sarcopenia Muscle 4: 31-39, 2013. https://doi.org/10.1007/s13539-012-0083-5

TARGOSOVA K, KUCERA M, KILIANOVA Z, SLOBODOVA L, SZMICSEKOVA K, HRABOVSKA A: Cardiac nicotinic receptors show $\beta$-subunit dependent compensatory changes. Am J Physiol Heart Circ Physiol 320: H1975-H1984, 2021. https://doi.org/10.1152/ajpheart.00995.2020

TVEDEN-NYBORG P, BERGMANN TK, LYKKESFELDT J: Basic \& Clinical Pharmacology \& Toxicology Policy for Experimental and Clinical studies. Basic Clin Pharmacol Toxicol 123: 233-235, 2018. https://doi.org/10.1111/bcpt.13059

WESSLER I, KIRKPATRICK CJ: Acetylcholine beyond neurons: the non-neuronal cholinergic system in humans. Br J Pharmacol 154: 1558-1571, 2008. https://doi.org/10.1038/bjp.2008.185 